\title{
Agnieszka Ciechelska*
}

Uniwersytet Ekonomiczny we Wrocławiu

\section{INNOWACJE W OCHRONIE LASÓW JAKO ELEMENT REALIZACJI ZIELONEJ GOSPODARKI}

\begin{abstract}
Streszczenie
Deforestacja i degradacja lasów, zwłaszcza tropikalnych, przyczynia się do efektu cieplarnianego i zmian klimatycznych i utraty bioróżnorodności. Głównym odbiorcą usług ekosystemowych lasów są kraje rozwinięte. Natomiast sprawcą deforestacji są kraje rozwijające się. Dlatego też konieczne są systemowe zmiany w sposobie funkcjonowania całych gospodarek krajowych poprzez realizację koncepcji zielonej gospodarki. Celem artykułu jest prezentacja możliwych rozwiązań służących ograniczeniu deforestacji lasów tropikalnych w kontekście zielonej gospodarki.
\end{abstract}

Słowa kluczowe: zielona gospodarka, obligacje leśne, ochrona lasów

\section{Wprowadzenie}

Obecny kryzys światowy jest największym od lat 30. ubiegłego wieku (Fiedor, 2010), gdyż kryzys finansowy i gospodarczy zbiegł się z kryzysem środowiskowym i rosnącym rozwarstwieniem społecznym (Stern, 2007). Dotychczas nie znaleziono satysfakcjonującego sposobu wythumaczenia jego przyczyn ani nie wypracowano modeli skutecznej poprawy sytuacji gospodarczej. Obecny system gospodarczy ge-

* E-mail: agnieszkaciech@poczta.onet.pl. 
neruje nie tylko kryzysy ekonomiczne, ale też kryzysy ekologiczne zagrażające bezpieczeństwu ludzi. Stało się to przyczynkiem do poszukiwania nowych priorytetów dla systemu gospodarczego i nowego sposobu gospodarowania (Ryszawska, 2014, s. 64). Głównym celem tak pojmowanego modelu wzrostu jest gospodarka niskoemisyjna i zasobooszczędna. Jednym z sektorów, który mógłby stać się istotnym elementem tak pojmowanej gospodarki, jest sektor leśny. Celem artykułu jest prezentacja rozwiązań gospodarczo-politycznych, służących skutecznemu ograniczeniu deforestacji i jednocześnie zapewniających wzrost gospodarczy zgodny z koncepcją zielonej gospodarki.

\section{Koncepcja zielonej gospodarki i jej obecność w strategii UE}

Koncepcja zrównoważonego rozwoju, a więc gospodarowania z uwzględnieniem możliwości środowiska i potrzeb społeczeństwa, przyświecała dotychczasowej realizacji polityki gospodarczej, jednak stanowiła raczej swoisty dodatek, niż integralną jej część. Praktyka pokazała, że realizacja tego holistycznego podejścia w praktyce jest niezwykle trudna. Ponadto obecny kryzys gospodarczy uwypuklił narastające problemy środowiskowe $i$ ich powiązanie ze sferą finansową i społeczną. Dlatego też zaczęto poszukiwać koncepcji, która będzie bardziej „skonkretyzowana" i możliwa do realizacji w stosunkowo krótkim horyzoncie czasowym. Tak też powstała koncepcja zielonej gospodarki, która przenika wszystkie polityki branżowe, a nie stanowi odrębnego elementu. Istotą zielonej gospodarki jest „rozwiązywanie" problemu środowiskowego w taki sposób, aby uzyskać wartość dodaną w postaci wzrostu gospodarczego. Jest to gospodarka niskoemisyjna, efektywnie wykorzystująca zasoby i zapewniająca integrację społeczną (Ferrot, 2011). Ponadto zapewnia wzrost gospodarczy, tworzy miejsca pracy, likwiduje ubóstwo poprzez inwestowanie i ochronę kapitału naturalnego, od którego zależy w długim okresie przetrwanie planety (Un-Dessa, 2013). Jednym z sektorów, który mógłby stać się istotnym elementem zielonej gospodarki, jest sektor leśny.

Obowiązująca strategia UE zakłada kierunek rozwoju zgodny z koncepcją zielonej gospodarki ${ }^{1}$. Koncepcja rozwoju zrównoważonego jest elementem nadrzędnym, przenikającym wszystkie inne polityki sektorowe i decydującym o osta-

${ }^{1}$ Nowa strategia UE, zastępująca strategię lizbońską, to Europa 2020, Strategia na rzecz inteligentnego i zrównoważonego rozwoju sprzyjającego włączeniu społecznemu. 
tecznym kształcie strategii. Zakłada się, że takie podejście pozwoli na uzyskanie wartości dodanej w postaci ożywienia gospodarki i nowych miejsc pracy. Strategia definiuje trzy podstawowe cele:

- rozwój inteligentny: rozwój gospodarki oparty na wiedzy i innowacji,

- rozwój zrównoważony: rozwój gospodarki zasobo- i energooszczędnej, ale jednocześnie konkurencyjnej,

- rozwój sprzyjający integracji społecznej: rozwój gospodarki z wysokim poziomem zatrudnienia, zapewniającym spójność społeczną i terytorialną (Komisja Europejska, 2010).

Szczegółowo kwestia zasobooszczędnej gospodarki została uregulowana w Strategii przystosowania się do zmian klimatu (UC, 2013). Chodzi o takie przemodelowanie sposobu gospodarowania, aby możliwa była równowaga i długookresowa kontynuacja funkcji ekosystemów, pomimo presji skutków zmian klimatycznych, oparte na rozwiązaniach niskoemisyjnych i zasobooszczędnych. Strategia główny nacisk kładzie na rozwój techniczny i technologiczny oraz stworzenie nowych miejsc pracy w takich sektorach jak: technologie rolne, gospodarowanie ekosystemami, budownictwo, gospodarka wodna i ubezpieczenia. Przedsiębiorstwa, a zwłaszcza MŚP, mogą stać się kreatorami nowych produktów i usług, odpornych na zmiany klimatu, wykorzystując możliwość prowadzenia działalności na całym świecie (EC,2013).

Zapobieganie i przystosowanie do zmian klimatycznych wymaga od krajów europejskich zaangażowania nie tylko w ramach rozwiązywania problemów krajowych, ale również problemów o charakterze globalnym. Jednym z takich obszarów są działania zmierzające do ograniczenia deforestacji i degradacji lasów tropikalnych. Ich znaczenie gospodarcze powoduje, że społeczności lokalne powodują nasilenie się tych procesów. Z drugiej jednak strony zdrowie tych ekosystemów jest jednym z kluczowych czynników wpływających na globalne zmiany klimatyczne. Dlatego też kraje europejskie powinny się zaangażować w ochronę lasów tropikalnych, tym bardziej, że daje to nowe możliwości rozwojowe, zgodne z koncepcją zielonej gospodarki.

\section{Znaczenie lasów}

Lasy dostarczają szeregu usług ekosystemowych mających kluczowe znaczenie dla równowagi naszej planety i funkcjonowania człowieka. Akumulują $\mathrm{CO}_{2} \mathrm{w}$ pro- 
cesie fotosyntezy (głównie w biomasie), retencjonują wodę, i regulują jej obieg w przyrodzie, wpływają na tworzenie się chmur, a tym samym warunki pogodowe, łagodzą gwałtowne wiatry, ograniczają erozję i powodzie, odbijają promieniowanie słoneczne i obniżają temperaturę (Kancelaria Senatu, 2010). Lasy są także potężnym magazynem naturalnych leków, pomysłów na rozwiązania techniczne i bankiem genów dla rolnictwa. Jako obszar o ogromnej bioróżnorodności są wykorzystywane przez społeczności lokalne do pozyskiwania bezpłatnych i różnorodnych dóbr, będących niekiedy przedmiotem handlu międzynarodowego. Rosnąca konsumpcja drewna, oleju palmowego, soi, kakao, kawy, gumy arabskiej, a także ekspansja górnictwa i hodowli bydła oraz budowa infrastruktury i rolnictwo stają się przyczyną coraz bardziej intensywnego wylesiania oraz coraz większych zniszczeń obszarów leśnych (Źórek, 2015). Wynika to z rosnącej populacji, jej rosnącego dochodu i zmian w modelu konsumpcji. Zmniejszenie powierzchni zalesionych powoduje, że zredukowane zostają możliwości akumulacji $\mathrm{CO}_{2}$ przez te obszary. Ponadto proces asymilacji $\mathrm{CO}_{2}$ przez lasy tropikalne jest też ograniczony ze względu na zmiany w tym ekosystemie, jakie powoduje bardziej lub mniej rabunkowa gospodarka leśna. Szacuje się, że deforestacja i degradacja lasów odpowiada za 17\% globalnej emisji gazów cieplarnianych (tj. utratę możliwości pochłaniania $\mathrm{CO}_{2}$ ), co jest porównywalne z emisją z sektora transportu (14\%) i energetycznego (21\%). Postępująca deforestacja i degradacja lasów, przyczynia się w znaczącym stopniu do zmian klimatycznych i utraty bioróżnorodności, a jednocześnie silnie oddziałuje na sytuację gospodarczą społeczności lokalnych i rynki międzynarodowe (Kim, Sexton, 2015).

Rozwiązanie tego problemu jest o tyle trudne, że sprawcami deforestacji są kraje rozwijające się, które realizując podobną ścieżkę rozwoju jak kraje rozwinięte, są „,skazane” na deforestację. Natomiast głównym beneficjentem usług środowiskowych świadczonych przez ekosystemy leśne są kraje rozwinięte. Rozbieżność interesów oraz świadomości ekologicznej i potrzeb rozwojowych powoduje, że problem ten nie może być rozwiązywany lokalnie. Konieczne jest zatem wypracowanie nowego podejścia o charakterze globalnym, zgodnego ze zrównoważonym rozwojem i realizującego założenia zielonej gospodarki. Celem artykułu jest prezentacja tego problemu i możliwych rozwiązań gospodarczo-politycznych, służących skutecznemu ograniczeniu deforestacji i jednocześnie zapewniających wzrost gospodarczy zgodny z ideą zielonej gospodarki. 


\section{Zachęty do ograniczenia deforestacji. Budowa zielonej gospodarki}

Dotychczasowe działania zapobiegające ${ }^{2}$ nie przyniosły zadowalających efektów. Dlatego też lasy, zwłaszcza tropikalne, powinny być poddane natychmiastowej, skutecznej ochronie poprzez włączenie szeroko rozumianych działań ochronnych w każde porozumienie międzynarodowe dotyczące zmian klimatycznych. Tym samym zostaną stworzone ekonomiczne podstawy do zaprzestania deforestacji, które jednocześnie będą przybliżać kraje rozwijające się do realizacji koncepcji zielonej gospodarki. Skuteczność takich działań będzie zapewniona dzięki objęciu nimi wszystkich sektorów wywierających presję na deforestację oraz kontroli przez społeczność międzynarodową. Powinny być one podejmowane równolegle w kilku płaszczyznach, m.in.:

- zmiany polityki i uregulowań prawnych (głównie rolnictwo, planowanie przestrzenne, polityka fiskalna),

- instrumentów finansowych, np. wprowadzenie dopłat dla właścicieli, którzy zdecydują się ograniczyć deforestację, czy płatności za usługi ekosystemowe,

- poprawie monitoringu i ochrony lasów; informacji o obszarach zalesianych, identyfikacji lasów poddawanych ochronie i tych zdegradowanych,

- zachęty do zmiany zachowań sektora prywatnego - odpowiednia oferta kredytowa i dotacyjna, zapewniająca ograniczenie deforestacji czy certyfikacja produktów rolnych i leśnych i wprowadzanie odpowiednich technik uprawy,

- inwestycji w ogólny rozwój ekonomiczny; m.in. pozyskanie kapitału i know-how w celu zmaksymalizowania produktywności w rolnictwie i górnictwie, rozwój produkcji wykorzystującej lasy, a niezwiązanej z produkcją drew$\mathrm{na}^{3}$, ułatwianie zakładania MŚP, inwestycje w infrastrukturę energetyczną i transportową (The Prince's..., 2013).

Wdrożenie tego rodzaju zintegrowanych działań ma na celu ochronę funkcji lasów tropikalnych, mających znaczenie dla globalnych zmian klimatycznych. Specyfika i złożoność tego ekosystemu oraz jego szeroki wachlarz usług ekosystemowych w powiązaniu z inwestycjami w branże wywierające presje na lasy i dostosowanie do lokalnej gospodarki pozwalają uzyskać efekty synergiczne. Dlatego też jest to

${ }^{2}$ Działania te były realizowane głównie w ramach programów dotacyjnych, finansowanych przez Komisję Europejską, Bank Światowy i Organizację Narodów Zjednoczonych oraz rządy: Norwegii, Japonii, Niemiec, Wielkiej Brytanii, Australii, Brazylii i Gujany (w ramach umów bilateralnych).

${ }^{3}$ Może to być produkcja owoców, kosmetyków, leków czy oferta usług ekoturystycznych. 
rozwiązanie tańsze, a jednocześnie o dużo większym zakresie niż inne działania, mające na celu ograniczenie zmian klimatycznych.

\section{Zmiany instytucjonalne}

Dla realizacji koncepcji zielonej gospodarki konieczna jest budowa nowego ładu instytucjonalnego w krajach rozwijających się. Główne zmiany to: zmiana polityki, utworzenie niezbędnych instytucji do jej realizacji, budowa systemu monitoringu oraz opracowanie planu działania. Wiąże się to ze stosunkowo wysokimi kosztami transakcyjnymi, które będą ponoszone w początkowym okresie transformacji. Środki finansowe powinny w większości pochodzić z krajów rozwiniętych jako sprawców deforestacji. Płatności powinny być dokonywane ex post, po weryfikacji efektów, np. wielkości obszarów leśnych. Płatności mogą być transferowane bezpośrednio na konto rządów krajów rozwijających się, za pośrednictwem operatora (instytucji powołanej do gromadzenia i efektywnego wydatkowania zgromadzonych środków) lub międzynarodowych rachunków do obsługi funduszu, za pośrednictwem instytucji międzynarodowych (jak dotychczas), bezpośrednio do beneficjentów na poziomie krajowym, m.in. do rządów, NGO i sektora prywatnego. Wysokość tych płatności może być oszacowana na podstawie utraconych możliwości, a te z kolei będą się zmieniać w czasie, np. ceny produktów rolnych będą rosły, sprawiając, że działalność rolnicza będzie bardziej opłacalna. Dlatego też dla stabilności systemu „kontrakty” powinny być podpisywane na okres kilkuletni.

Dla sprawnego systemu finansowania i ochrony lasów konieczne będzie stworzenie informatycznego systemu monitoringu lasów - krajowego (służącego inwentaryzacji) i międzynarodowego (do weryfikacji postępów realizacji porozumień). Dla ograniczenia kosztów transakcyjnych tego rozwiązania możliwe jest wykorzystanie istniejących już sieci naukowych i badawczych.

Tworzenie nowego ładu instytucjonalnego wymaga transparentności i włączenia wszystkich interesariuszy w procesy decyzyjne. Takie podejście oznacza automatycznie konieczność włączenia w procesy decyzyjne lokalnych społeczności, rdzennej ludności, sektora prywatnego, NGO i rządów lokalnych. Jest to o tyle ważne, że tylko niektóre działania będą realizowane na szczeblu rządowym. Większość będzie dotyczyć podmiotów gospodarczych i to one muszą być przekonane o ich słuszności. Również instytucje finansowe obsługujące środki finansowe przeznaczone na re- 
dukcję deforestacji muszą być transparentne i realizować najwyższe standardy oraz uwzględniać specyfikę poszczególnych krajów czy podmiotów gospodarczych.

\section{Instrumenty finansowe}

Dotychczas stosowane instrumenty, głównie o charakterze dotacyjnym czy też pożyczki preferencyjne, nie spełniły oczekiwań w zakresie rozwiązania problemu deforestacji. Dlatego też konieczne są tu rozwiązania innowacyjne, takie jak płatności za ograniczenie deforestacji oraz obligacje leśne. Płatności za ograniczenie deforestacji byłyby swoistą rentą za utracone korzyści. Wycena ich wartości mogłaby być oparta na udziale sektora drzewnego w globalnym PKB lub na korzyściach z ograniczenia zmian klimatycznych. Możliwe są również inne sposoby wyceny, np. jako wartość kapitału naturalnego dla danego kraju, liczona jako WTP ${ }^{4}$ społeczności światowej w celu ograniczenia emisji $\mathrm{CO}_{2}$ (Government of Guyana, 2010). Płatnikiem tych zobowiązań byłyby kraje rozwinięte, jako że to one są największym beneficjentem usług ekosystemowych lasów tropikalnych. Jest to też podyktowane różnymi możliwościami rozwojowymi krajów rozwijających się i rozwiniętych. Dlatego też kraje rozwinięte mogłyby przyjąć na siebie dodatkowe limity emisji $\mathrm{CO}_{2}$, gdyż ochrona lasów deszczowych jest najszybszym i najtańszym sposobem redukcji tej emisji.

Obligacje leśne są jednym z najbardziej innowacyjnych źródeł finansowania ograniczenia deforestacji i w przyszłości mogą stać się najistotniejszym. Tego rodzaje obligacje mogą być atrakcyjne zwłaszcza dla banków centralnych oraz inwestorów instytucjonalnych, zwłaszcza inwestujących etycznie. Szacuje się, że rynek ten będzie wart około 10 mld dolarów każdego roku (The Prince's..., 2009). Byłyby to bezpieczne papiery wartościowe, wyrażone w jednej lub kilku różnych walutach i byłyby gwarantowane przez rządy krajów rozwiniętych i międzynarodowe instytucje finansowe, co zapewniałoby, że są to instrumenty bezpieczne, o ratingu AAA. Zabezpieczenie multiinstytucjonalne pozwoli na ustalanie wyższej stopy zwrotu niż średnia rynkowa. Okres wykupu obligacji może się wahać od roku do 40-50 lat ${ }^{5}$.

${ }^{4}$ Skłonność do zapłaty liczona jest w tym wypadku jako suma wartości drewna, wartość terenu, koszty ochrony lasów, wartość utraconych usług ekosystemowych w wymiarze lokalnym i globalnym.

${ }^{5}$ Dla tego rodzaju obligacji okres zwrotu powinien wynosić co najmniej 10 lat, co wynika z potrzeb inwestorów instytucjonalnych i specyfiki ochrony lasów. 
Możliwe są różne schematy wypłaty korzyści, co wiąże się z różnym obciążeniem gwaranta. Obligacje amortyzowane wymagają stosunkowo wysokich, równych płatności każdego roku aż do okresu wykupu. Natomiast obligacje kuponowe wymagają niewielkich corocznych płatności i dużego wydatku w okresie wykupu, a obligacje zerokuponowe wszelkie płatności przesuwają na okres wykupu (IFC World Bank Group, 2012).

\section{Środki krajowe}

Do efektywnej ochrony lasów konieczne jest też finansowe zaangażowanie krajów porośniętych lasami tropikalnymi, które dotychczas było znikome. Środki z sektora prywatnego można by pozyskać poprzez różnego rodzaju podatki. Przykładowo mógłby być to system narzutów na cenę dóbr przyczyniających się do deforestacji, takich jak żywność, pasza, wełna, minerały. Oczywiste, że rządy krajów rozwijających się będą niechętnie podchodziły do tego rodzaju regulacji. Dlatego też pewną rekompensatą mogłyby być szczególne warunki dla dóbr produkowanych poza tymi sektorami. Ocenia się, że dobre rezultaty przyniesie certyfikacja i odpowiednie zapisy dotyczące zamówień publicznych. Szacuje się, że około 20\% produkcji drewna trafia do sektora publicznego (The Prince s..., 2009). Różne podmioty sektora prywatnego mogłyby wspólnie pracować nad opracowaniem kryteriów zrównoważonego produktu czy usługi i rozwijać systemy certyfikacji, a w dalszej kolejności współpracę tylko z certyfikowanymi partnerami.

Najbardziej pożądanym kierunkiem inwestowania środków krajowych jest sektor górnictwa, który w znaczącej mierze przyczynia się do deforestacji. Nowe inwestycje pozwalają na zwiększenie efektywności wydobycia i przetwarzania surowca. Oznacza to maksymalizację korzyści przy jednoczesnej minimalizacji kosztów środowiskowych i jednocześnie może przynieść skutki w postaci zwiększenia liczby miejsc pracy i wytwarzania bardziej przetworzonych dóbr. Ponadto środki krajowe należy przeznaczać na edukację, opiekę zdrowotną oraz budowę infrastruktury transportowej i energetycznej, co będzie przeciwdziałać marginalizacji różnych grup społecznych. W konsekwencji pozwoli to na ograniczenie pozyskiwania nowych gruntów pod uprawę czy hodowlę i pozyskiwanie drewna, zwłaszcza w sposób nielegalny. 


\section{Podsumowanie}

Niewątpliwie innowacyjne podejście do ochrony lasów, zwłaszcza tropikalnych, choć z uwzględnieniem różnic rozwojowych, przyniesie korzyści całemu światu. Podstawą tych rozwiązań staje się transakcja kupna sprzedaży usług ekosystemowych lasów. Stroną podażową transakcji są kraje rozwijające się, a popytową - rozwinięte. Przy czym cena będzie tym wyższa, im oferent dokona większych pozytywnych zmian w posiadanym na swoim terenie zasobie leśnym. Sposób realizacji tych zmian może być bardzo szeroki i nie dotyczyć wyłącznie sektorów bezpośrednio związanych z lasami. Skutkiem „ubocznym” takiego systemu będzie przyczynienie się do rozwiązania globalnego problemu zmian klimatycznych w sposób trwały poprzez zmianę gospodarowania w krajach rozwijających się. Ta zmiana ma polegać na transformacji w stronę zielonej gospodarki. Synergia uzyskanych efektów oraz innowacyjne podejście pozwolą na znaczne obniżenie kosztów transakcyjnych. Kolejną korzyścią wprowadzenia takich rozwiązań będą zmiany na rynku kapitałowym. Płatności krajów rozwiniętych mogłyby być realizowane w formie aukcji pozwoleń, realizowanych jako część europejskiego systemu handlu uprawnieniami do emisji (EU Emission Trading Scheme-ETS). Mógłby być to instrument atrakcyjny dla sektora ubezpieczeniowego, który zabezpieczałby aktywa przed ryzykiem katastrof. Najbardziej jednak innowacyjnym rozwiązaniem są obligacje leśne, które mogłyby być szczególnie atrakcyjne dla inwestorów instytucjonalnych, a zwłaszcza funduszy emerytalnych, gdyż są to papiery bezpieczne, których wartość rośnie w stosunkowo krótkim okresie, a wykup następuje w długim okresie. Tak pojmowana ochrona lasów pozwoli nie tylko na rozwiązywanie problemów środowiskowych, ale i osiąganie długookresowych zmian w systemie społeczno-gospodarczym, takich jak zmiana struktury przemysłu, zmiana wzorców konsumpcji czy systemów wartości.

\section{Literatura}

European Commission. (2013). The EU Strategy on Adaptation to Climate Change, $\mathrm{COM} / 2013 / 0216$ final.

Fiedor, B. (2010). Kryzys gospodarczy a kryzys ekonomii jako nauki. Ekonomista, 4. 
Frerot, A. (2011). Unia Europejska a wyzwanie stworzenia zielonej gospodarki. Kwestie Europejskie, 206.

Government of Guyana. (2010). Forest carbon Partnership Facility (FCPF) Readiness Preparation Proposal.

IFC World Bank Group. (2012). Forest-backed bonds proof of Concept Study, Issue Brief.

Kancelaria Senatu, Biuro Analiz i Dokumentacji, Dział Analiz i Opracowań Tematycznych. (2010). Zielona księga - Ochrona lasów i informacje o lasach w UE: przygotowanie lasów na zmianę klimatu. Opracowania tematyczne, OT-585.

Komisja Europejska. (2010). Europa 2020, Strategia na rzecz inteligentnego i zrównoważonego rozwoju sprzyjajacego włączeniu społecznemu, Komunikat Komisji Europejskiej. Bruksela.

Kim, D.H., Sexton, J.O., Townshend, J.R. (2015), Accelerated deforestation in the humid tropics from the 1990s to the 2000s. Geophysical Research Letters, 42 (9), 3495-3501.

Ryszawska, B. (2013). Zielona gospodarka - teoretyczne podstawy koncepcji i pomiar jej wdrażania w Unii Europejskiej. Wrocław: Wydawnictwo Uniwersytetu Ekonomicznego we Wrocławiu.

Stern, N. (2007). The Economics of climate Change. The Stern Review. Cambridge: Cambridge University Press.

The Prince's Rainforests Project. (2009). An Emergency Package for Tropical Forests.

UN-DESA. (2012). A Guidebook to the Green Economy. Issue 3: exploring green economy policies and international experience with national strategies.

Żórek, R. (2015). Ekonomiczna wartość lasu: inne usługi systemowe. Aura, 7. DOI: 10.151 99/2.2015.7.3.

\title{
INNOWATIONS IN FOREST PROTECTION AS AN ELEMENT OF GREEN ECONOMY REALIZATION
}

\begin{abstract}
Deforestation and degradation of forests, especially tropical ones, contributes to the greenhouse effect and climate change and loss of biodiversity. Developed countries are the main recipients of forest's ecosystem services. However the perpetrators of deforestation are developing countries. Therefore, it is necessary to entire systematic changes in national
\end{abstract}


economies through the implementation of the idea of a green economy. The aim of the article is to present possible solutions to reduce deforestation of tropical forests in the context of the green economy.

\section{Translated by Agnieszka Ciechelska}

Keywords: green economy, forest bonds, forest protection

Kod JEL: 044 
